\title{
GENETIC ANALYSIS FOR YIELD AND ITS COMPONENT TRAITS UNDER WATER STRESS CONDITION IN RICE (Oryza sativa, L.) \\ Abd El-Hadi, A. H. ${ }^{1}$; H. F El-Mowafi ${ }^{2}$ and E. A. Ramadan ${ }^{3}$ \\ 1- Genetics Dept.,Faculty of Agriculture, Mansoura University. \\ 2- Rice Research and Training Center, Sakha, Kafr El-Sheikh, Egypt. \\ 3- Biotechnology Lab, Rice Research and Training Center, Sakha, Kafr El-Sheikh, Egypt.
}

\begin{abstract}
Seven rice genotypes differed in their drought tolerance along with their 21 $F_{1}$ crosses obtained from a partial diallel crosses mating design were evaluated under water stress condition at the research farm of Rice Research and Training Center (RRTC), Sakha, Kafr El-Sheikh, Egypt during the two growing seasons of 2010 and 2011 to identify the superior parents and hybrids and to determine the appropriate breeding methods under this condition. The results indicated that, mean squares were highly significant for all studied traits indicating the presence of wide range of genetic variations among the parental lines used in this study. GCA/SCA ratio was greater than unity for panicles plant ${ }^{-1}$; panicle weight and 1000-grain weight traits suggesting the preponderance of additive type of gene action in these materials. The ratio was less than unity for grain yield plant ${ }^{-1}$, spikelet fertility percentage, filled grains panicle ${ }^{-1}$ and harvest index suggesting the preponderance of non-additive gene action. The drought tolerant parents: IRAT170; Moroberekan and Azuciena were the best general combiners for most yield and its component traits. High GCA effects showed the presence of favorable genes with additive type of gene action. Therefore, a multiple crossing program involving good general combiners found in the current study is recommended. Highly significant positive SCA effects were obtained by the cross Giza177 x Azuceina for all traits and the cross IR64 x Moroberekan for all traits except panicles plant ${ }^{-1}$. Based on SCA effects among the 21 crosses, the desirable crosses were eight for grain yield plant $^{-1}$; seven for panicles plant ${ }^{-1}$; five for panicle weight; six for 1000-grain weight; nine for filled grains panicle ${ }^{-1}$; eight for spikelet fertility percentage and eleven for harvest index. $F_{1}$ hybrids were recommended because of their good SCA for yield and its component traits under water stress condition. The heritability estimates in broad sense were high for all traits and ranged from $86.3 \%$ for harvest index to $98.07 \%$ for filled grains panicle ${ }^{-1}$. Low estimates of heritability in narrow sense were recorded for harvest index (14.62\%); spikelets fertility percentage $(16.03 \%)$ and grain yield plant $^{-1}(17.53 \%)$. In contrary, the degree of dominance values were higher than unity for spikelets fertility percentage; harvest index and grain yield plant ${ }^{-1}$ traits indicating that the effect was of over-dominance type.
\end{abstract}

\section{INTRODUCTION}

Rice (Oryza sativa, L.) is one of the world's most important crops, providing a staple food for nearly half of the global population (FAO, 2004). In Egypt, rice is considered the second important cereal crop, following wheat, as a main food for the Egyptian population (Bastawisi et al., 2003).

Drought is a severe abiotic stress which would cause serious losses in yield and productivity for most crops in arid and semi-arid regions (Atkinson 
et al., 2000 and Massonnet et al., 2007). Thus, water stress is the major environmental factor that constrains the productivity and stability of crops (Araus et al., 2002). It is estimated that, more than $50 \%$ of the world rice production area is affected by drought (Bouman et al., 2005). Egypt is selfsufficient in rice, but due to a high population growth rate, presence of new diseases and pests, the ongoing process of climate changes and declines Egypt's share of the River Nile water; rice production would be declined to insufficient levels. The development of drought-tolerant varieties which maintain good yield under drought or water stress is of major priority for rice research for sustainable rice production.

There are three basic drought patterns affecting rice production i.e. early (occurring during vegetative growth, after establishment but before maximum tillering), intermittent, and late (occurring after panicle initiation) drought stresses. Yield reduction from early drought stress is often minimal and mainly results from a reduction in tillers number (Jongdee et al., 2006). Intermittent or continuous drought stress, occurring between the tillering and flowering stages, may greatly reduce yield as a result of reduced leaf expansion and photosynthesis (Fukai and Cooper, 1995). Late drought that occurs during later growing stages, especially during flowering, reduced spikelets fertility is the main factor contributing to yield loss (Liu et al., 2006).

Plants are most susceptible to water stress at the reproductive stage; Dramatic reduction of grain yield occurs when stress coincides with the irreversible reproductive processes, making the genetic analysis of drought tolerance at the reproductive stage crucially important (Boonjung and Fukai, 2000 and Pantuwan et al., 2002).

Many studies on yield and its component traits in rice were reported by Abd Allah et al., (2010); Muthuramu et al., (2010) and Ali et al., (2012); for general combining ability (GCA) and specific combining ability (SCA) and by Gaballah (2009); Ali et al., (2012); Seyoum et al., (2012) and Sohrabi et al., (2012) for heritability in broad sense and in narrow sense.

The main objective of the present study was to assess combining ability; heritability and degree of dominance for yield and its component traits for several genotypes and their crosses under water stress condition and to identify the most desirable genotypes which would be used as a donor parents and as a best combiners in the rice breeding program.

\section{MATERIALS AND METHODS}

This study was carried out at the research farm of Rice Research and Training Center (RRTC), Sakha, Kafr El-Sheikh, Egypt during the two growing seasons of 2010 and 2011. Seven rice genotypes varied in their drought tolerance were utilized in this study. Name, pedigree, origin, type and some features of the studied genotypes are presented in Table 1. The parental genotypes were grown during 2010 growing season in three successive dates of planting of fifteen days intervals in order to overcome the differences in flowering time for each parent. At flowering stage the bulk emasculation method was practiced using hot water according to Jodon 
(1938) and modified by Butany (1961). A partial diallel crossing was made among the seven parental genotypes to produce $21 F_{1}$ hybrids. The $F_{1}$ seeds were separately harvested from each cross, and saved for sowing in the next season of 2011 .

In 2011 growing season, seeds from each the genotype (crosses and their parents) were sown in the nursery. After thirty days from sowing, seedlings were individually transplanted in the permanent field in one row. Each row was five meters long with $20 \mathrm{~cm}$ between rows comprised 25 hills each thinned to single plant. The experiment was laid out in Randomized Complete Blocks Design (RCBD) with three replications. Plants were only irrigated every 12 days using flushing irrigation. All agricultural practices were carried out according to the recommendations of rice plantation. At reproductive stage, five plants were randomly selected from each genotype. Data were recorded on yield and yield component traits which included panicles plant $^{-1}$; panicle weight $(\mathrm{g})$; 1000-grain weight $(\mathrm{g})$; filled grains panicle $^{-1}$; spikelets fertility percentage (\%); grain yield plant $^{-1}(\mathrm{~g})$ and harvest index (\%).

Genetic analysis to estimate general combining ability (GCA) and specific combining ability (SCA) was performed using the Griffing (1956) method-2, model-1.

\section{RESULTS AND DISCUSSION}

\section{Analysis of variance:-}

The estimated values of mean squares for yield and its component traits are presented in Table 2. The mean squares of genotypes, parents and crosses were highly significant for all studied traits indicating the presence of wide range of genetic variations among the parental lines. The highly significant values of mean square of parents versus crosses for all studied traits indicated that heterosis was significant for these traits.

The results emphasized the importance of combining ability studies and indicated good prospects for selection of suitable parents and crosses for the development of appropriate varieties and hybrids. Both GCA and SCA variances were highly significant for all the studied traits indicating the importance of both additive and non-additive genetic variances in the inheritance of the studied traits (Rahimi et al., 2010). GCA/SCA ratios were greater than unity for panicles plant ${ }^{-1}$, panicle weight $(\mathrm{g})$ and 1000-grain weight $(\mathrm{g})$ suggesting the preponderance of additive type of gene action in the inheritance of these traits.

On the other hand, GCA/SCA ratios were less than unity for grain yield plant ${ }^{-1}$, spikelet fertility percentage (\%), filled grains panicle ${ }^{-1}$ and harvest index (\%) suggesting the preponderance of non-additive type of gene action in the inheritance of these traits which might be resulted from dominance, epistasis and interaction effects. These results indicated that there is a very good prospect for the exploitation of non-additive genetic variances of yield traits through the production of hybrids. Similar results were also reported by Gopikannan and Ganesh (2013). 


\section{General combining ability effects (GCA):-}

Combing ability analysis provides guide line for the assessment of relative breeding potential of the parents and help in the choice of the parents (Gnanasekaran et al., 2006) which may be hybridized either to exploit hybrid vigor by accumulating unfixable gene effects or to evolve into cultivars by accumulating fixable gene effects (Nadarajan and Gunasekaran, 2005). The additive gene effect is distinguished by GCA while, the non-additive effect is distinguished by SCA (Choukan, 2008)

The general combining ability effects (GCA) of each parent are shown for yield and yield component traits in Table 3 . The results indicated the presence of desirable positive and highly significant GCA effects for the drought tolerant parents IRAT170 for most traits except for panicles plant ${ }^{-1}$ and spikelets fertility percentage (\%) which showed undesirable either highly significant or non-significant negative estimates, respectively. The parental genotype Moroberekan showed the same trend for most traits except for panicles plant $^{-1}$ and harvest index, while the parental genotype Azuciena showed the same for most traits except for panicles plant ${ }^{-1}$; grain yield plant ${ }^{-1}$ and harvest index. Therefore, these parents were considered as good combiners for most yield and its component traits under drought condition.

The three parents i.e. IR64, Giza178 and IET1444 were found to be desirable showing highly significant positive GCA effect for panicles plant ${ }^{-1}$, therefore these parents are considered as good combiners for this trait. Three parents i.e. Moroberekan, Azuceina and IRAT170 exhibited highly significant positive GCA effects for panicle weight (g); 1000-grain weight (g) and filled grains panicle ${ }^{-1}$, therefore these parents are the best combiners for these traits. The parental genotype Giza177 showed significant positive GCA effect for 1000-grain weight.

The best combiners for spikelets fertility percentage (\%) were the two parents: Moroberekan and Azuceina. In the same way, both parents: IRAT170 and Moroberekan were the best general combiners for grain yield plant $^{-1}$, where they revealed highly significant and significant positive GCA effects, respectively. In the case of harvest index, the drought tolerant parent IRAT170 followed by both Egyptian rice varieties; Giza177 and Giza178 were the best general combiners for this trait. Similar results under drought stress condition were obtained by Abd Allah et al., (2010) for tillers plant ${ }^{-1}$, Ali et al., (2012) for panicles plant ${ }^{-1}$, panicle weight, spikelets fertility percentage (\%) and Muthuramu et al., (2010) and Ali et al., (2012) for grain yield plant ${ }^{-1}$. High GCA effects indicate the presence of favorable genes with additive type of gene action. Therefore, a multiple crossing program involving good general combiner parents would be recommended as superior genotypes as proposed by Nadarajan and Gunasekaran (2005).

\section{Specific combining ability effects (SCA):-}

Estimates of specific combining ability effects (SCA) for yield and its component traits are presented in Table 4. Desirable and highly significant positive SCA effects for all traits were observed for the cross Giza177 x Azuceina, meanwhile the cross IR64 x Moroberekan exhibited highly significant positive SCA effects for all studied traits except for panicles plant ${ }^{-1}$. For grain yield plant ${ }^{-1}$; among $21 \mathrm{~F}_{1}$ crosses, eight crosses i.e. Giza178 $\mathrm{x}$ 
Moroberekan; Giza178 x Azuceina; IET1444 x IRAT170; Giza177 x Moroberekan; IR64 x Moroberekan; Giza177 x IET1444; IR64 x Azuceina and IR64 $\times$ IET1444 were found to be good specific combiners based on their significant positive SCA effects. These results are in agreement with those obtained by Panwar (2005); Petchiammal and Kumar (2007) and Saleem et al., (2010) who reported several promising specific combiners based on their high mean performance and the magnitude at their SCA effects for grain yield plant $^{-1}$ in rice. For other traits, significant positive SCA effects were observed for seven crosses i.e. Giza178 x IRAT170; IET1444 x Moroberekan; IR64 x IET1444; Giza177 x Azuceina; IET1444 x Azuceina; Giza178 x Moroberekan and IET1444 $\times$ IRAT170 for panicles plant $^{-1}$, five crosses i.e. IR64 $\times$ Moroberekan; Giza177 x Azuceina; IET1444 x IRAT170; Giza177 x IRAT170 and IRAT170 x Moroberekan for panicle weight, six crosses i.e. IR64 x Moroberekan; IR64 x IRAT170; IET1444 x Azuceina; Giza177 x Giza178; Giza177 x Azuceina and Giza177 x IET1444 for 1000- grain weight, nine crosses i.e. IRAT170 x Moroberekan; IR64 x Giza178; Giza177 x IET1444; Giza177 x Moroberekan; IET1444 x IRAT170; IR64 x Moroberekan; Giza177 $x$ Azuceina; Giza178 x Azuceina and Moroberekan x Azuceina for filled grains panicle $^{-1}$, eight crosses i.e. Giza178 x IET1444; IR64 x Giza178; Giza177 x Azuceina;

Giza177 x IRAT170; Giza177 x Moroberekan; IR64 x Moroberekan; IRAT170 $x$ Moroberekan and IR64 x Azuceina for spikelets fertility percentage and eleven crosses i.e. Giza177 x Azuceina; Giza178 x Azuceina; Giza177 x Moroberekan; Giza177 x IET1444; Giza178 x Moroberekan; IR64 x IRAT170; IR64 x Moroberekan; IR64 x IET1444; Giza177 x IRAT170; IET1444 x IRAT170 and IR64 x Giza178 for harvest index. Significant SCA effects were also reported by Panwar (2005) and Saleem et al., (2010) for harvest index and Ali et al., (2012) for panicles plant $^{-1}$, spikelets panicle ${ }^{-1}$, spikelets fertility percentage (\%), grain weight and grain yield plant ${ }^{-1}$. 
Abd El-Hadi, A. H. et al.

2-3- 
J.Agric.Chem.and Biotechn., Mansoura Univ.Vol. 5(1): January, 2014

4 
Heterosis breeding is recommended for good specific combiners which were identified in the present investigation for yield and its component traits. High SCA effects show the predominance of non-additive gene effects mainly dominance gene effects (Nadarajan and Gunasekaran, 2005).

Crosses which show non-significant SCA effects but originated from parents having high GCA effects (additive gene effects) would be used for recombination breeding with early selection of desirable segregants (Nadarajan and Gunasekaran, 2005). These crosses were IR64 x Giza178 for panicles plant ${ }^{-1}$; IRAT170 $\times$ Moroberekan for 1000-grain weight and grain yield plant ${ }^{-1}$; IRAT170 $x$ Azuceina for filled grains panicle ${ }^{-1}$ and Moroberekan $x$ Azuceina for spikelets fertility percentage (\%).

Crosses which indicated high estimates for SCA effects and derived from parents having high GCA effects would also be used in good recombination in to produce good hybrids. However, the selection of superior genotypes to develop good cultivars must be delayed to later generations to allow fixation of maximum homozygosity (Nadarajan and Gunasekaran, 2005). These crosses were IR64 x IET1444 for panicles plant ${ }^{-1}$; IRAT170 $x$ Moroberekan for panicle weight; Giza177 x Azuceina for 1000-grain weight; Moroberekan $x$ Azuceina and IRAT170 $x$ Moroberekan for filled grains panicle $^{-1}$ and Giza177 x IRAT170 for harvest index.

\section{Genetic components:-}

The estimates of phenotypic variance $\left(\delta^{2} p\right)$; heritability in broad sense $\left(h^{2}{ }_{b} \%\right)$; heritability in narrow sense $\left(h^{2} \%\right)$ and degree of dominance (d') are presented in Table 5.

\section{Phenotypic variance:-}

As shown in Table 5, the estimates of phenotypic variances ranged from 1.17 to 1653.5 revealing a wide range of variations among all the studied traits. The highest estimates of phenotypic variances were observed for filled grains panicle ${ }^{-1}$ and spikelet fertility percentage (\%) traits. On the other hand, the lowest value of variance was obtained by panicle weight. The additive genetic variances were larger than both dominance and environmental variances for panicles plant $^{-1}$, panicle weight, 1000-grain weight and filled grains panicle ${ }^{-1}$ traits.

Heritability in broad sense $\left(\mathrm{h}^{2} \mathrm{~b} \%\right)$ :-

The results in Table 5 showed that broad sense heritability estimates were high for all studied traits and ranged from $86.3 \%$ for harvest index to $98.07 \%$ for Filled grains panicle ${ }^{-1}$. These findings are in agreement with those obtained by Gaballah (2009) and Ali et al., (2012) who reported high estimates of heritability in broad sense for yield and yield component traits under water stress condition. Similar results were also obtained by Sohrabi et al., (2012); Ullah et al., (2011) and Singh et al., (2011) for grain yield plant ${ }^{-1}$ and spikelets panicle ${ }^{-1}$; Sohrabi et al., (2012) and Seyoum et al., (2012) for 1000-grain weight; Sohrabi et al., (2012) for spikelet fertility percentage; Ullah et al., (2011) and Babu et al., (2012) for filled grains panicle ${ }^{-1}$; Ullah et al., (2011) for panicles plant ${ }^{-1}$ and Singh et al., (2011) for harvest index. 
Table 5: Estimates of genetic components for all studied traits under drought condition.

\begin{tabular}{|c|c|c|c|c|c|c|c|}
\hline Trait & $\delta^{2} e$ & $\delta^{2} p$ & $\delta^{2} \mathrm{~A}$ & $\delta^{2} \mathrm{D}$ & $\mathbf{h}^{2} \%$ & $\mathbf{h}^{2}{ }_{n} \%$ & d' $^{\prime}$ \\
\hline Panicles plant $^{-1}$ & 0.83 & 25.87 & 19.7 & 5.34 & 96.8 & 76.17 & 0.521 \\
\hline Panicle weight $(\mathrm{g})$ & 0.13 & 1.71 & 1.26 & 0.32 & 92.17 & 73.3 & 0.504 \\
\hline 1000 -grain weight $(\mathrm{g})$ & 0.56 & 15.44 & 11.62 & 3.26 & 96.35 & 75.26 & 0.530 \\
\hline Filled grains panicle ${ }^{-1}$ & 31.87 & 1653.5 & 901.08 & 720.54 & 98.07 & 54.5 & 0.894 \\
\hline $\begin{array}{l}\text { Spikelets fertility } \\
\text { percentage (\%) }\end{array}$ & 7.23 & 298.73 & 47.88 & 243.62 & 97.58 & 16.03 & .256 \\
\hline Grain yield plant $^{-1}(\mathrm{~g})$ & 1.64 & 50.37 & 8.83 & 39.9 & 96.75 & 17.53 & 2.126 \\
\hline Harvest index (\%) & 6.11 & 44.61 & 6.52 & 31.98 & 86.3 & 14.62 & 2.215 \\
\hline
\end{tabular}

$\delta^{2} \mathrm{e}=$ environmental variance; $\delta^{2} \mathrm{p}=$ phenotypic variance; $\delta^{2} \mathrm{~A}=$ additive variance; $\delta^{2} \mathrm{D}=$ dominance variance; $h^{2}{ }_{b} \%=$ heritability in broad sense, $h^{2}{ }_{n} \%=$ heritability in narrow sense and $d^{\prime}=$ degree of dominance.

Heritability in narrow sense $\left(h^{2}{ }_{n} \%\right)$ :-

The $h_{n}{ }_{n}$ heritability estimates were considered to be low when their values were below $30 \%$; medium when their values ranged from 30 to $60 \%$ and high when their values were above $60 \%$ as reported by Babu et al., (2012).

Low estimates of heritability in narrow sense ranged from 14.62 to $28.23 \%$ were recorded for harvest index; spikelets fertility percentage and grain yield plant $^{-1}$. The heritability estimates were medium for filled grains panicle $^{-1}$ trait. The low estimates of heritability for these traits suggested that, the major part of phenotypic variation was due to non-additive and environmental variance, therefore phenotypic selection for such traits must be done in the late generations. These results agreed with those obtained by Ebrahim (2009) for harvest index and Ali et al., (2012) for panicles plant ${ }^{-1}$ and grain yield plant ${ }^{-1}$.

High estimates of heritability in narrow sense ranged from 66.24 to $76.17 \%$ were obtained for panicle weight; panicles plant $^{-1}$ and 1000 -grain weight traits. The high heritability estimates of these traits cleared that, a major part of the total phenotypic variance was due to additive genetic variance, thus effective phenotypic selection for these traits would be achieved with satisfactory degree of accuracy in early generations. Similar results were obtained by Ali et al., (2012) for panicle weight and grain weight and Ebrahim (2009) for 1000-grain weight.

Degree of dominance $\left(d^{\prime}\right)$ :-

The estimates of degree of dominance for all studied traits are presented in Table 5. When the value of a trait is equal to the unity, then the trait is under control of the complete dominance. When the value is more than unity, the trait is affected by over-dominance. On the other hand, when the value is less than unity this means that the trait is controlled by partial dominance. The degree of dominance values ranged from 0.504 to 2.256. The values were higher than unity for spikelets fertility percentage; harvest index and grain yield plant ${ }^{-1}$ traits indicating that their mode of inheritance was of over-dominance. Meanwhile, other traits exhibited values lower than unity suggesting that they were under partial-dominance effect. These results are in common agreement with those obtained by Ali et al., (2012) for grain 
yield plant $^{-1}$; panicle weight; panicles plant $^{-1}$ and spikelets panicle ${ }^{-1}$ under drought stress condition.

\section{REFERENCES}

Abd Allah, A. A.; A. A. A. Mohamed and M. M. GabAllah(2009). Genetic studies of some physiological and shoot characters in relation to drought tolerance in rice. Journal of Agricultural Research Kafrelsheikh University, 35(4): 964-993.

Ali, A. A.; H. F. El-Mowafi and A. A. Aboulila(2012). Genetical and biochemical analysis for drought tolerance associated traits in rice (Oryza sativa, L.). Journal of Agricultural Research Kafrelsheikh University, 38 (2): 284-308.

Araus, J. L.; G. A. Slafer; M. P. Reynolds and C. Royo(2002). Plant breeding and relations in $\mathrm{C} 3$ cereals: what to breed for? Annals of Botany, 89: 925- 940.

Atkinson, C. J.; M. Policarpo; A. D. Webster and G. Kingswell(2000). Drought tolerance of clonal Malus determined from measurements of stomatal conductance and leaf water potential. Tree Physiology, 20(8): 557-563.

Babu, V. R.; K. Shreya; K. S. Dangi; G. Usharani and P. Nagesh(2012). Genetic variability studies for qualitative and quantitative traits in popular rice (Oryza sativa, L.) hybrids of india. International Journal of Scientific and Research Publications, 2(6): 1-5.

Bastawisi, A. O.; H. F. El-Mowafi; M. A. Maximos and M. F. Sabaa(2003). Hybrid rice production technology in Egypt. Proceedings: Workshop on rice integrated crop management systems for food security in the near east countries, 27-29 July, Alexandria, Egypt.

Boonjung, H. and S. Fukai(2000). Effects of soil water deficit at different growth stages on rice growth and yield under upland conditions. 2. Phenology, biomass production and yield. Field Crops Research, 43: 47-55.

Bouman, B. A. M.; S. Peng; A. R. Castaòeda and R. M. Visperas(2005). Yield and water use of irrigated tropical aerobic rice systems. Agricultural Water Management, 74(2): 87-105.

Butany, W. T. (1961). Mass emasculation in rice. International Rice Commission Newsletter, 9: 9-13.

Choukan, R.(2008). Methods of genetical analysis of quantitative traits in plant breeding. $1^{\text {st }}$ Edn, Agricultural Extension, Education and Research Organization, pp: 270.

Ebrahim, G. B. A.(2009). Breeding for earliness and some agronomic characters in rice (Oryza sativa, L.). M. Sc. Thesis, Faculty of Agriculture, Tanta University, Egypt.

[FAO] Food and Agriculture Organization of the United Nations(2004). The state of food and agriculture 2003-2004. Agricultural Biotechnology: Meeting the Needs of the Poor?

Fukai, S. and M. Cooper(1995). Development of drought resistant cultivars using physio-morphological traits in rice. Field Crops Research, 40: 6786. 
Gaballah, M. M.(2009). Studies on physiological and morphological traits associated with drought resistance in rice (Oryza sativa, L.). Ph. D. Thesis, Faculty of Agriculture, Kafrelsheikh Unversity, Egypt.

Gnanasekaran, M.; P. Vivekanandan and S. Muthuramu(2006). Combining ability and heterosis for yield and grain quality in two line rice (Oryza sativa, L.) hybrids. The Indian Journal of Genetics and Plant Breeding, 66(1): 6-9.

Gopikannan, M. and S. K. Ganesh(2013). Investigation on combining ability and heterosis for sodicity tolerance in rice (Oryza sativa, L.). African Journal of Agricultural Research, 8(32): 4326-4333.

Griffing, B.(1956). Concept of general and specific combining ability in relation to diallel crossing systems. Australian Journal of Biological Sciences, 9: 463-493.

Jodon, N.E. (1938). Experiments on artificial hybridization of rice. Journal of the American Society of Agronomy, 30 (4): 294-305

Jongdee, B; G. Pantuwan; S. Fukai and K. Fischer(2006). Improving drought tolerance in rainfed lowland rice: an example from Thailand. Agric. Water Manage, $80: 225-240$.

Liu, J. X.; D. Q. Liao; R. Oane; L. Estenor; X. E. Yang; Z. C. Li and J. Bennett(2006). Genetic variation in the sensitivity of anther dehiscence to drought stress in rice. Field Crops Research, 97: 87-100.

Massonnet, E. C.; R. Serge; D. Erwin and J. L. Regnard(2007). Stomatal regulation of photosynthesis in apple leaves: Evidence for different water-use strategies between two cultivars Catherine. Annals of Botany, 100(6): 1347-1356.

Muthuramu, S.; S. Jebaraj; R. Ushakumari and M. Gnanasekaran(2010). Estimation of combining ability and heterosis for drought tolerance in different locations in rice (Oryza sativa, L.). Electronic Journal of Plant Breeding, 1(5): 1279- 1285.

Nadarajan, N. and M. Gunasekaran(2005). Quantitative genetics and biometrical techniques in plant breeding. Kalyani Publ., New Delhi, pp: 258.

Pantuwan, G.; S. Fukai; M. Cooper; S. Rajatasereekul and J. C. O'Toole(2002). Yield response of rice (Oryza sativa, L.) genotypes to different types of drought under rainfed lowlands. 3. Plant factors contributing to drought resistance. Field Crops Research, 73: 181-200.

Panwar, L .L.(2005). Line $\times$ tester analysis of combining ability in rice (Oryza sativa, L.). Ind. J. Genet., 65(1): 51-52.

Petchiammal, K. I. and C. R. A. Kumar(2007). Combining ability studies for yield and yield associated traits in rice (Oryza sativa, L.) involving Assam rice cultivars. Int. J. Agric. Sci., 3(2): 234-236.

Rahimi, M.; B. Rabiei; H. Samizadeh and A. K. Ghasemi(2010). Combining ability and heterosis in rice (Oryza sativa, L.) cultivars. Journal of Agricultural Science and Technology, 12: 223-231.

Saleem, M. Y.; J. I. Mirza and M. A. Haq(2010). Combining ability analysis of some morpho-physiological traits in basmati rice. Pakistan Journal of Botany, 42(5): 3113-3123 
Seyoum, M.; S. Alamerew and K. Bantte(2012). Genetic variability, heritability, correlation coefficient and path analysis for yield and yield related traits in upland rice (Oryza sativa, L.). Journal of Plant Sciences, 7: 13-22.

Singh, S. K.; C. M. Singh and G. M. Lal(2011). Assessment of genetic variability for yield and its component characters in rice (Oryza sativa, L.). Research in Plant Biology, 1(4): 73-76.

Sohrabi, M.; M. Y. Rafii; M. M. Hanafi; A. S. N. Akmar and M. A. Latif(2012). Genetic diversity of upland rice germplasm in Malaysia based on quantitative traits. The Scientific World Journal, 11: 1-9

Ullah, M. Z.; M. K. Bashar; M. S. R. Bhuiyan; M. Khalequzzaman and M. J. Hasan(2011). Interrelationship and cause-effect analysis among morpho-physiological traits in biroin rice of Bangladesh. International Journal of Plant Breeding and Genetics, 5: 246-254.

$$
\begin{aligned}
& \text { التحليل الوراثي لصفات المحصول ومكوناته تحت ظرف الاجهاد المسائي في الارز } \\
& \text { (Oryza sativa, L.) }
\end{aligned}
$$

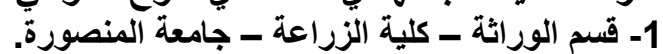

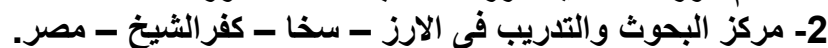

$$
\begin{aligned}
& \text { 3- معمل البيوتكنولوجي - مركز البحوث والتوريب في الارز - سخا ـ كفرالثيخ - مصر. }
\end{aligned}
$$

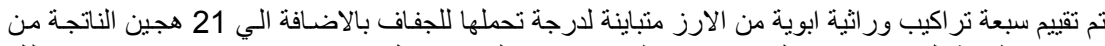

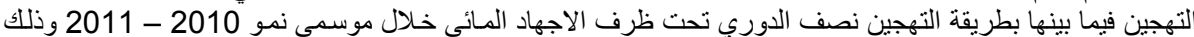

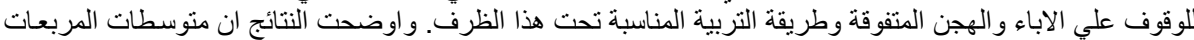

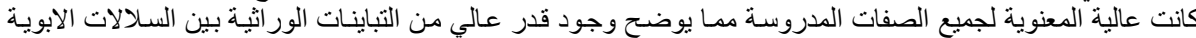

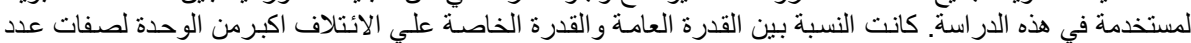

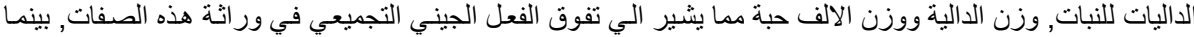

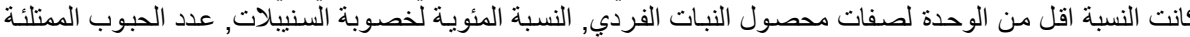

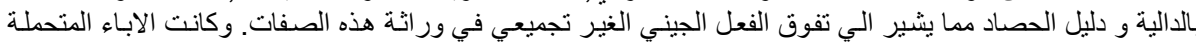

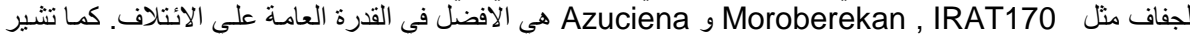

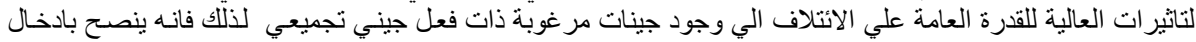

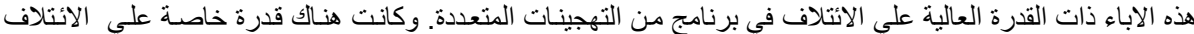

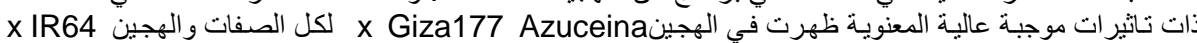

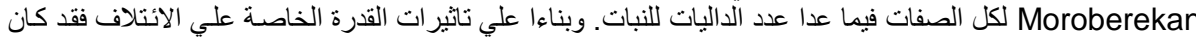

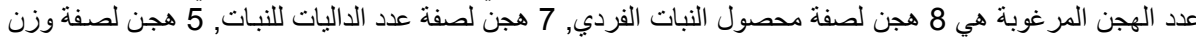

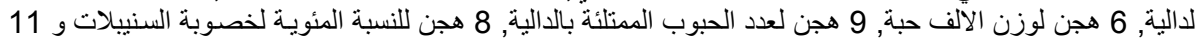

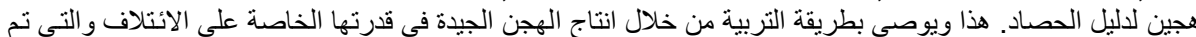

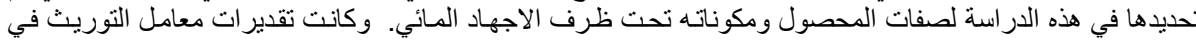

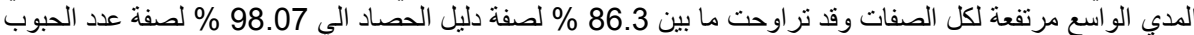

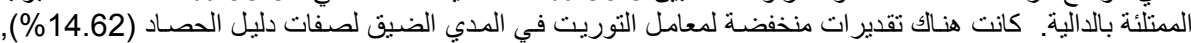

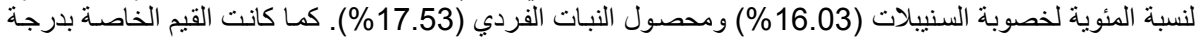

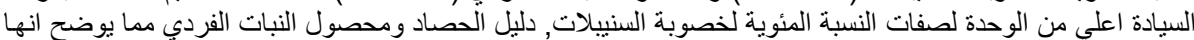
تحت ناثير ألسيادة الفائقة.

$$
\text { كلية الزراعة - جامعة المنصورة }
$$


Table 1: Name, origin, type, pedigree and some features of the parental genotypes.

\begin{tabular}{|lllll|}
\hline Genotypes & Origin & Type & Parentage & Features \\
\hline Giza177 & Egypt & Japonica & Giza171/Yomji No1 // Pi No4 & Drought sensitive \\
IR64 & IRRI & Indica & IR5657-33-2-1/IR2061-465-1-5-5 & Drought sensitive \\
Giza178 & Egypt & Indica/Japonica & Giza175/Milyang 49 & Moderately drought tolerance \\
IET1444 & India & Indica & TN1/CO29 & Moderately drought tolerance \\
IRAT170 & Côte d'Ivoire & Japonica & IRAT13/ Palawan & Drought tolerance \\
Moroberekan & Republic of Guinea & Tropical japonica & IR8-24-6 (M307H5) & Drought tolerance \\
Azuciena & Philippines & Japonica & - & Drought tolerance \\
\hline
\end{tabular}

Table 2: Mean square estimates of ordinary analysis and combining ability analysis for yield and yield

\begin{tabular}{|c|c|c|c|c|c|c|c|c|}
\hline $\begin{array}{ll}\text { S.o.v. Traits } & \\
\end{array}$ & df & $\begin{array}{l}\text { Panicles } \\
\text { plant }^{-1}\end{array}$ & $\begin{array}{c}\text { Panicle } \\
\text { Weight(g) }\end{array}$ & $\begin{array}{l}\begin{array}{c}1000-\text { grain } \\
\text { weight }(\mathrm{g})\end{array} \\
\end{array}$ & $\begin{array}{c}\text { Filled grains } \\
\text { panicle }^{-1}\end{array}$ & $\begin{array}{l}\text { Spikelet fertility } \\
\text { Percentage }(\%)\end{array}$ & $\begin{array}{l}\text { Grain yield } \\
\text { plant }^{-1}(g)\end{array}$ & $\begin{array}{c}\text { Harvest } \\
\text { Index (\%) }\end{array}$ \\
\hline Reps & 2 & 0.22 & 0.36 & 0.18 & 60.80 & 7.30 & 22.77 & 2.38 \\
\hline Genotypes & 27 & $74.05^{\star *}$ & $4.92^{* \star}$ & $44.16^{\star *}$ & $4480.12^{* *}$ & $733.78^{\star \star}$ & $112.52^{\star *}$ & $124.51^{\star *}$ \\
\hline Parents & 6 & $100.76^{* *}$ & $6.11^{* *}$ & $61.17^{* *}$ & $3046.54^{\star *}$ & $158.49^{* *}$ & $58.11^{\star \star}$ & $47.15^{\star *}$ \\
\hline Crosses & 20 & $58.12^{\star \star}$ & $4.64^{\star \star}$ & $39.23^{* *}$ & $5078.68^{* *}$ & $789.86^{\star \star}$ & $94.88^{\star *}$ & $152.16^{\star *}$ \\
\hline Parents Vs. Crosses & 1 & $232.40^{\star \star}$ & $3.34^{\star *}$ & $40.72^{\star \star}$ & $1110.48^{\star *}$ & $3063.94^{\star *}$ & $791.69^{\star *}$ & $35.54^{\star *}$ \\
\hline G.C.A & 6 & $89.50^{\star \star}$ & $5.78^{\star *}$ & $52.87^{\star *}$ & $4086.73^{\star *}$ & $222.67^{\star \star}$ & $35.46^{\star \star}$ & $41.37^{\star \star}$ \\
\hline S.C.A & 14 & $6.16^{* *}$ & $0.46^{* *}$ & $3.82^{\star *}$ & $752.42^{\star *}$ & $250.86^{* *}$ & $38.09^{* *}$ & $41.54^{\star \star}$ \\
\hline Error ( $\mathrm{Me})$ & 54 & 2.48 & 0.40 & 1.69 & 95.62 & 21.70 & 18.33 & 4.92 \\
\hline G.C.A / S.C.A & & 1.85 & 1.94 & 1.78 & 0.63 & 0.10 & 0.10 & 0.11 \\
\hline
\end{tabular}

and ${ }^{*}:$ Significant at 0.05 and 0.01 levels of probability,respectively.G.C.A=General combining ability and S.C.A=Specific combining ability.

Table 3: Estimates of general combining ability effects (GCA) for yield and yield component traits for seven parents under drought conditions.

\begin{tabular}{|c|c|c|c|c|c|c|c|}
\hline \begin{tabular}{|ll} 
Parents & Traits \\
\end{tabular} & $\begin{array}{l}\text { Panicless } \\
\text { plant }^{-1}\end{array}$ & $\begin{array}{c}\text { Panicle } \\
\text { weight }(g)\end{array}$ & $\begin{array}{c}1000- \\
\text { Grain weigh }\end{array}$ & $\begin{array}{c}\text { Filled } \\
\text { t (g) grains panicle }{ }^{-1}\end{array}$ & $\begin{array}{c}\text { Spikelets } \\
\text { Fertility percentage (\%) }\end{array}$ & $\begin{array}{l}\text { Grain yield } \\
\text { plant }^{-1}(\mathrm{~g})\end{array}$ & $\begin{array}{l}\text { Harvest } \\
\text { Index (\%) }\end{array}$ \\
\hline Giza177 & $-0.667^{\star}$ & $-0.490^{* *}$ & $0.574^{*}$ & $-18.058^{* *}$ & $-4.703^{\star *}$ & $-2.574^{\star \star *}$ & $1.002^{*}$ \\
\hline IR64 & $2.763^{* \star}$ & $-0.589^{\star *}$ & $-1.030^{* *}$ & $-18.243^{\star \star}$ & $-4.622^{* *}$ & -0.755 & $-1.326^{* *}$ \\
\hline Giza178 & $2.789^{\star \star}$ & $-0.799^{* *}$ & $-3.704^{\star \star}$ & $-11.836^{\star \star}$ & 0.555 & -0.354 & $0.950^{*}$ \\
\hline IET1444 & $4.085^{\star *}$ & $-0.647^{\star *}$ & $-2.344^{\star *}$ & $-17.466^{\star \star}$ & $-4.705^{\star *}$ & $-2.039^{* *}$ & $-2.822^{\star *}$ \\
\hline IRAT170 & $-2.578^{\star \star}$ & $0.609^{\star *}$ & $2.607^{\star \star}$ & $12.683^{\star *}$ & 1.054 & $2.793^{\star *}$ & $3.820^{\star *}$ \\
\hline Moroberekan & $-3.344^{\star *}$ & $0.999^{* *}$ & $2.304^{* *}$ & $31.905^{\star *}$ & $7.673^{* *}$ & $1.662^{*}$ & $-0.958^{*}$ \\
\hline Azuceina & $-3.048^{\star \star}$ & $0.917^{\star \star}$ & $1.593^{\star \star}$ & $21.016^{\star \star}$ & $4.748^{\star \star}$ & 1.267 & -0.666 \\
\hline LSD 0.05 & 0.563 & 0.227 & 0.465 & 3.493 & 1.664 & 1.529 & 0.792 \\
\hline LSD 0.01 & 0.750 & 0.302 & 0.619 & 4.652 & 2.216 & 2.037 & 1.055 \\
\hline
\end{tabular}

${ }^{*}$ and ${ }^{* *}$ : Significant at 0.05 and 0.01 levels of probability, respectively. 
Table 4: Estimates of specific combining ability effects (SCA) for yield and yield component traits of 21 crosses

\begin{tabular}{|c|c|c|c|c|c|c|c|}
\hline crosses traits & $\begin{array}{l}\text { Panicles } \\
\text { plant }^{-1}\end{array}$ & $\begin{array}{c}\text { Panicle } \\
\text { weight }(g)\end{array}$ & \begin{tabular}{|l|}
$\begin{array}{l}\text { 1000- grain } \\
\text { weight }(g)\end{array}$ \\
\end{tabular} & $\begin{array}{c}\text { Filled } \\
\text { Grains panicle }^{-1} \\
\end{array}$ & $\begin{array}{c}\text { Spikelets fertility } \\
\text { Percentage (\%) }\end{array}$ & $\begin{array}{l}\text { Grain Yield } \\
\text { plant }^{-1}(\mathrm{~g})\end{array}$ & $\begin{array}{l}\text { Harvest } \\
\text { Index (\%) }\end{array}$ \\
\hline Giza177 x IR64 & 0.170 & $-1.020^{\star *}$ & 0.397 & $-32.806^{* *}$ & $-27.501^{* *}$ & -2.528 & $-4.968^{\star *}$ \\
\hline Giza177 x Giza178 & 0.611 & $-0.646^{*}$ & $2.205^{\star *}$ & $-33.213^{* *}$ & $-34.214^{\star *}$ & $-6.690^{\star *}$ & $-10.407^{* *}$ \\
\hline Giza177 x IET1444 & 0.415 & 0.351 & $1.612^{* *}$ & $28.417^{* *}$ & $-4.284^{\star}$ & $5.845^{* *}$ & $5.135^{* *}$ \\
\hline Giza177 x IRAT170 & 0.378 & $0.749^{\star *}$ & -0.206 & 4.935 & $10.174^{\star *}$ & 2.764 & $3.413^{* *}$ \\
\hline Giza177 x Moroberekan & -0.156 & 0.539 & -1.003 & $26.713^{* *}$ & $9.475^{\star *}$ & $5.901^{* *}$ & $7.234^{* *}$ \\
\hline Giza177 x Azuceina & $2.448^{* *}$ & $0.984^{* *}$ & $1.675^{* *}$ & $19.269^{* *}$ & $10.813^{\star *}$ & $6.760^{* *}$ & $8.219^{* *}$ \\
\hline IR64 x Giza178 & 0.781 & 0.463 & 0.342 & $31.306^{\star *}$ & $13.515^{\star *}$ & 1.511 & $2.237^{*}$ \\
\hline IR64 x IET1444 & $2.985^{\star \star}$ & 0.107 & $-4.384^{* *}$ & 3.269 & -3.229 & $4.223^{*}$ & $3.620^{* *}$ \\
\hline IR64 x IRAT170 & 1.148 & -0.289 & $2.964^{\star \star}$ & $-25.213^{* *}$ & $-6.025^{\star *}$ & 3.672 & $4.247^{* *}$ \\
\hline IR64 x Moroberekan & 0.681 & $1.128^{* *}$ & $3.868^{* *}$ & $22.565^{\star *}$ & $5.980^{* *}$ & $5.876^{* *}$ & $3.711^{* *}$ \\
\hline IR64 x Azuceina & 0.285 & 0.470 & 0.145 & -7.213 & $3.891^{*}$ & $5.574^{* *}$ & -0.554 \\
\hline Giza178 x IET1444 & $-1.441^{*}$ & 0.228 & 0.423 & -3.806 & $13.865^{\star *}$ & 3.625 & $3.517^{* *}$ \\
\hline Giza178 x IRAT170 & $3.989^{* *}$ & $-0.719^{*}$ & $-1.262^{*}$ & $-12.620^{* *}$ & $-12.751^{* *}$ & -0.396 & $-5.098^{\star *}$ \\
\hline Giza178 x Moroberekan & $2.089^{* \star}$ & 0.272 & $-1.625^{\star *}$ & 3.491 & -2.279 & $6.931^{* *}$ & $5.003^{* *}$ \\
\hline Giza178 x Azuceina & -0.807 & 0.234 & 0.353 & $19.046^{\star *}$ & $-4.852^{* *}$ & $6.473^{* *}$ & $7.284^{* *}$ \\
\hline IET1444 x IRAT170 & $1.726^{*}$ & $0.822^{* *}$ & 0.312 & $23.343^{* *}$ & 1.075 & $6.235^{\star *}$ & $2.444^{*}$ \\
\hline IET1444 x Moroberekan & $3.759^{\star \star}$ & $-0.967^{* *}$ & 0.349 & $-47.880^{* *}$ & $-23.086^{\star *}$ & $-7.991^{\star *}$ & $-12.219^{\star *}$ \\
\hline IET1444 x Azuceina & $2.230^{* *}$ & -0.505 & $2.294^{* *}$ & $-39.657^{* *}$ & $-26.555^{* *}$ & $-9.245^{\star *}$ & $-13.577^{* *}$ \\
\hline IRAT170 x Moroberekan & 0.156 & $0.653^{*}$ & 0.164 & $49.972^{\star *}$ & $3.431^{*}$ & 0.688 & -1.251 \\
\hline IRAT170 x Azuceina & -0.974 & -0.248 & -0.758 & 4.528 & $-3.488^{\star}$ & -0.424 & -0.499 \\
\hline Moroberekan x Azuceina & -0.307 & -0.191 & 0.579 & $9.639^{*}$ & 2.821 & -1.583 & 0.395 \\
\hline LSD 0.05 & 1.393 & 0.561 & 1.150 & 8.645 & 3.384 & 3.785 & 1.961 \\
\hline LSD 0.01 & 1.855 & 0.747 & 1.532 & 11.513 & 4.507 & 5.041 & 2.611 \\
\hline
\end{tabular}

${ }^{*}$ and ${ }^{* *}$ : Significant at 0.05 and 0.01 levels of probability, respectively. 
